\title{
Causes of Project Delay in the Construction Industry in Afghanistan
}

\author{
Ghulam Abbas Niazai and Kassim Gidado
}

\begin{abstract}
It is widely accepted that a project is successful when it is finished on time but unfortunately, due to many reasons, in Afghanistan a large number of construction projects fail to meet their original contact time. Construction delays are the most serious problems which send bad signals to foreign investors thereby slowing down the national development. A comprehensive survey; therefore, on time performance of various construction projects was carried out to identify the critical factors that cause construction delays in Afghanistan.

From in-depth literature studies, eighty three causes of delay were identified. Questionnaires were then developed and sent to 60 carefully selected construction industry stakeholders including: clients, contractors, and consultants in Afghanistan. The findings show that the main critical factors that cause construction delays in Afghanistan are: security, corruption, poor qualification of the contractor's technical staff, payment delays by clients, and poor site management and supervision by contractor. This paper also explores and provides some recommendations to reduce the impact of delays on construction projects in Afghanistan.
\end{abstract}

Keywords: Construction projects, Delay causes, Afghanistan

\section{Introduction}

Delay is a major problem in construction industry. Trauner et al. (2009) defines that construction delays make something happen later than expected, to cause something to be performed later than planned, or to not act timely. Delay can affect any activity of work in a schedule and results in many problems between parties. According to Al-Khalil and AlGhafly (1999) delays can adversely impact on project stakeholders, such as clients, contractors and designers. To the client, delay perceives loss of revenue due to lack of rentable space or lack of production facilities. On the other hand, delay can be meant to the contractor as higher overhead costs, higher material and labour costs because the project takes longer than it was planned.

Having finished the projects on time (Assaf and Al-Hejji, 2006) can be marked as an indicator of efficiency, but the construction activities involves of many unpredictable factors and variables arisen from various sources. These resources may include environmental circumstances, availability of resources, stakeholders' performance and contractual relations. Nevertheless, Trauner et al. (2009) states that it is hardly ever occur that a construction project is finished within the planned time. 


\section{Literature Review}

Many researches and articles have been carried out on causes of delay in construction projects. The findings of such studies have been reviewed for this research. Chan and Kumaraswamy (1997) did a survey to assess the relative importance of 20 potential delay factors in Hong Kong construction projects and five key factors were found, such as poor risk management and supervision, unforeseen site conditions, slow decision making, client-initiated variations, and work variations. However, Al-Momani (2000) in a research on construction delays in 130 public projects in Jordan found that weather, site conditions, late deliveries, economic conditions and increase in quantity are the critical factors which cause construction delays in Jordan construction industry.

Kaming et al. (1997) carried out a research to study the impact factors on 31 high-rise projects in Indonesia and it was found that time overrun is less severe than cost overruns. The significant factors that lead to cost overrun are material fluctuation, inaccurate material estimation and degree of complexity. Whereas, design changes, poor labor productivity, inadequate planning, and resource shortages are marked as time overruns.

Mezher \& Tawil (1998) carried out a research in to find out the Causes of delays in the construction industry in Lebanon. A total of 64 causes of delays were identified through research in which client, contractor and consultant were undertaken the study. All three parties generally agreed on the ranking of the major categories of delay factors. Owners had more concerns with regard to financial issues, while contractors ranked contractual relationships highest, and finally, consultants firms ranked project management highest. These causes were categorized in 10 main groups: materials, manpower, equipment, financing, changes, government relations, project management, site conditions, environment and contractual relationships. Long et al. (2008) conducted a study to find out the cause of delays and cost overrun in Vitinam and 7 critical factors were identified such as, Slowness and Lack of constraint; Incompetence; Design; Market and Estimate; Financial capability; Government; and Worker.

Assaf and Al-Hejji (2006) studied the causes of delay in large building construction projects in Saudi Arabia. They found 73 factors that cause construction delays. They categorized these factors into 9 groups. Some of the most important causes of delay included approval of shop drawings, delays in contractors' payment by owners, design changes by owners, cash problems during construction, the slowness of the owners' decision-making process, design errors, excessive bureaucracy in project-owner organization, labour shortages and inadequate labour skills.

Assaf et al. (1995) identified 56 main causes of delay in Saudi large building construction projects and their relative importance. Based on the contractors surveyed the most important delay factors were: preparation and approval of shop drawings, delays in contractor's progress, payment by owners and design changes. Koushki et al. (2005) carried out a research in Kuwait and identified estimates of time delays and cost increases and their causes. The three main causes of delays are changing orders, owners' financial constraints, and owners' lack of experience. And three first causes of cost overruns are contractor- related problems, material-related problems and owners' financial constraints.

\section{Objectives of the study}

The following objectives are developed to achieve the aim of the research 
1. To identify the causes of delays in construction industry in Afghanistan

2. To study the differences in ideas of the three main stakeholders, including clients, contractors and consultants.

3. To identify the significant factors that causes delays in Afghanistan.

The aim of first objective is to identify the list of factors that cause construction delays, while the third objective focuses on the top ten causes of construction delays.

\section{Research Methodology}

The research conducted in this study is mostly exploratory in nature. Both primary and secondary data are used in this research, and data has been obtained through two primary avenues - desk research and questionnaire. Firstly, from in-depth literature studies and discussing with some construction practitioners, eighty three causes of delay were identified, which is presented in Table 1. Then, a questionnaire form was developed in order to evaluate the effects of the factors that cause construction delays.

Firstly, a pilot study was conducted to verify whether the questions are relevant in respect to the objectives of the study. The pilot study was conducted in the University of Brighton and the questions were discussed with the research supervisor and two other senior lecturers. The questionnaires included with a cover letter were sent to 60 construction practitioners, including, clients, contractors, and consultants. The construction parties, who actively involved in Afghanistan construction industry, were asked to response the questionnaires.

The questionnaire was divided into two main parts. Part one includes the details of the respondents and organizations in order to get the information about the respondent's details and organization as well. Part two includes factors that cause construction delays in Afghanistan. This part is comprised of nine categories such as, projects itself; client, contractor, consultant, designer, materials, equipment, labor, and external factors. The questions were based on the Likert's scale of five ordinal measures from 1 to 5 (very low effect to very high effect) according to level of contributing.

Data were collected through questionnaire forms and importance index were used to analyze the data gathered. Agreement between each two parties in respect to the causes of delays was also tested. In light of findings of the research, recommendations for minimizing the impact of delays were made.

\section{Data Analysis Method}

The following statistical techniques and index were used for analyzing the data collected: Importance Index: The most frequent index used for construction delays is Importance Index $I_{p}$. According to Long et al. (2008) to rank different factors from various groups of causes the Relative Importance Index $I_{p}$ is an appropriate index for analyzing construction delays. It is computed as below:

$$
I_{p}=\frac{\sum_{i=1}^{5} a_{i} \cdot n_{i}}{5 N}
$$


Where: $\mathrm{a}=$ constant expressing the weight assigned to each responses (ranging from 1 very low effects to 5 very high effects), $\mathrm{n}=$ frequency of the responses for each cause and $\mathrm{N}=$ total number of responses

\subsection{Spearman's Rank Correlation}

According to Assaf and Al-Hejji (2006) spearman's rank correlation is a non-parametric test. Correlation is a relationship measure among different parties or factors and the strength and direction of the relationship. This method mainly used to show the degree of agreement between the different parties. The correlation coefficient varies between +1 and -1 , where +1 implies a perfect positive relationship (agreement), while -1 results from a perfect negative relationship (disagreement). The value near to zero indicates little or no correlation. In this research this correlation is used to find out the degree of agreement between parties. This correlation is computed by the following formula:

$r_{s^{\prime}}=1-\left(\frac{6 \sum d^{2}}{n\left(n^{2}-1\right)}\right.$

Where: $r_{S^{\prime}}$ is the Spearman rank correlation coefficient between two parties, $\mathrm{d}$ is the difference between ranks assigned to variables for each cause and $n$ is the number of pairs of rank.

Table 1. List of causes of delay categorized into nine groups

\begin{tabular}{|cll|}
\hline No & Causes of Delay & Group \\
\hline 1 & Original contract duration is too short & Project \\
2 & Legal disputes b/w various parties & Project \\
3 & Inadequate definition of substantial completion & Project \\
4 & Ineffective delay penalties & Project \\
5 & Type of construction contract (Turnkey, and etc.) & Project \\
6 & Type of project bidding and award (negotiation, lowest price, etc.) & Project \\
7 & Delay in progress payments by owner & Client \\
8 & Delay to furnish and deliver the site to the contractor by the owner & Client \\
9 & Change orders by owner during construction & Client \\
10 & Late in revising and approving design documents by owner & Client \\
11 & Delay in approving shop drawings and sample materials & Client \\
12 & Poor communication and coordination by owner and other parties & Client \\
13 & Slowness in decision making process by owner & Client \\
14 & Conflicts between joint-ownership of the project & Client \\
15 & Unavailability of incentives for contractor & Client \\
16 & Suspension of work by owner & Client \\
17 & Difficulties in financing project by contractor & Contractor \\
18 & Conflicts in sub-contractors schedule in execution of project Contractor & Contractor \\
19 & Rework due to errors during construction & Contractor \\
20 & Conflicts b/w contractor and other parties (consultant and owner) & Contractor \\
21 & Poor site management and supervision by contractor & Contractor \\
22 & Poor communication and coordination by contractor with other parties & Contractor \\
23 & Ineffective planning and scheduling of project by contractor & Contractor \\
24 & Improper construction methods implemented by contractor & Contractor \\
25 & Delays in sub-contractors work & Contractor \\
26 & Inadequate contractor's work & Contractor \\
27 & Frequent change of sub-contractors because of their inefficient work & Contractor \\
28 & Poor qualification of the contractor's technical staff & Contractor \\
29 & Delay in site mobilization & Contractor \\
\hline
\end{tabular}




\begin{tabular}{|c|c|c|}
\hline 30 & Delay in performing inspection and testing by consultant & Consultant \\
\hline 31 & Delay in approving major changes in the scope of work by consultant & Consultant \\
\hline 32 & Inflexibility (rigidity) of consultant & Consultant \\
\hline 33 & Poor communication/coordination between consultant and other parties & Consultant \\
\hline 34 & Late in reviewing and approving design documents by consultant & Consultant \\
\hline 35 & Conflicts between consultant and design engineer & Consultant \\
\hline 36 & Inadequate experience of consultant & Consultant \\
\hline 37 & Mistakes and discrepancies in design documents & Designer \\
\hline 38 & Delays in producing design documents & Designer \\
\hline 39 & Unclear and inadequate details in drawings & Designer \\
\hline 40 & Complexity of project design & Designer \\
\hline 41 & Insufficient data collection and survey before design & Designer \\
\hline 42 & Misunderstanding of owner's requirements by design engineer & Designer \\
\hline 43 & Inadequate design-team experience & Designer \\
\hline 44 & Un-use of advanced engineering design software & Designer \\
\hline 45 & Shortage of construction materials in market & Materials \\
\hline 46 & Changes in material types and specifications during construction & Materials \\
\hline 47 & Delay in material delivery & Materials \\
\hline 48 & Damage of sorted material while they are needed urgently & Materials \\
\hline 49 & Delay in manufacturing special building materials & Materials \\
\hline 50 & Late procurement of materials & Materials \\
\hline 51 & Late in selection of finishing materials due to diversity in market & Materials \\
\hline 52 & Equipment breakdowns & Equipment \\
\hline 53 & Shortage of equipment & Equipment \\
\hline 54 & Low level of equipment-operator's skill & Equipment \\
\hline 55 & Low productivity and efficiency of equipment & Equipment \\
\hline 56 & Lack of high-technology mechanical equipment & Equipment \\
\hline 57 & Wrong selection & Equipment \\
\hline 58 & Shortage of labors & Labor \\
\hline 59 & Unqualified workforce & Labor \\
\hline 60 & Nationality of labors & Labor \\
\hline 61 & Low productivity level of labors & Labor \\
\hline 62 & Personal conflicts among labors & Labor \\
\hline 63 & Weak motivation & Labor \\
\hline 64 & Security & External \\
\hline 65 & Warlords influence & External \\
\hline 66 & Corruption & External \\
\hline 67 & Natural disasters ( flood, landslides, ...) & External \\
\hline 68 & Effects of subsurface conditions (e.g., soil, high water table, etc.) & External \\
\hline 69 & Inclement weather (very cold, very hot, rain...) & External \\
\hline 70 & Unavailability of utilities in site & External \\
\hline 71 & Effect of social and cultural factors & External \\
\hline 72 & Traffic control and restriction at job site & External \\
\hline 73 & Accident during construction & External \\
\hline 74 & Delay in providing services from utilities (such as water, electricity) & External \\
\hline 75 & Permits from municipality & External \\
\hline 76 & Permits for foreign labourers & External \\
\hline 77 & Building codes & External \\
\hline 78 & Bureaucracy in Government agencies & External \\
\hline 79 & Permit from the urban planning bureau & External \\
\hline 80 & Permit from Order of Engineers & External \\
\hline 81 & Changes in government regulations and laws & External \\
\hline 82 & Poor government judicial system for construction dispute settlement & External \\
\hline 83 & Market inflation & External \\
\hline
\end{tabular}




\section{Research findings and results}

\subsection{General characteristics of respondents}

Out of 60 set of questionnaires distributed, with the proportion of (20 for clients, 25 for contractors, and 15 for consultants), 24 questionnaires were fully responded. Whereas, 3 set of questionnaires were not correctly filled in, hence the 21 set of questionnaires which were useable for the analysis. The feedbacks comprise of $33 \%$ clients, $42 \%$ contractors and $25 \%$ consultants which forms $35 \%$ of total responses. $48 \%$ respondents have less than 5 years, $33 \%$ between 5 - 15 years and $19 \%$ who have more than 15 years experience.

\subsection{Ranking of delay causes}

The causes of delays were ranked on the basis of Importance Index explained earlier from the viewpoint of three stakeholders (clients, contractors and consultants). The list of causes which is categorized into nine groups is presented in Table 1.

\subsection{Importance delay of causes}

The importance index was used to rank the effect of each cause of delay. Table 2 presents the 10 key factors ranked by clients, contractors, and consultants. Two causes of delay are common between all parties, which are 'security' and 'corruption'. Both clients and consultants reported that poor qualification of the contractor's technical staff and difficulties in financing project by contractor are the most sever causes of delay by the contractors. Contractors reported that delay in progress payment by the client is one of the significant causes of delay. Consultants like clients agreed that ineffective planning and scheduling of project by contractor is another key driver in delaying projects in Afghanistan.

\subsection{Significant causes of delay}

The importance index was employed to rank the significant causes of delay. All three parties, including clients, contractors and consultants contributed to rank the significant factors of delays. The result in Table 3 shows that the top 10 major causes of construction delays in Afghanistan are security with importance rank of 0.913 and corruption with importance rank of 0.830 followed by poor qualification of the contractor's technical staff, poor site management and supervision by contractor, ineffective planning and scheduling of project by contractor, and difficulties in financing project by contractor. Delay in progress payments by owner and type of project bidding and award (negotiation, lowest price) are another critical factors which result in delays. The finding clearly indicates that 'Bureaucracy in Government agencies' is also one of the key sources of construction delays in Afghanistan. Bureaucracy leads to lengthy and complex payment process in government agencies, and the process can take as long as four to five months. These 10 significant causes of delays are strongly contributing to construction delays in Afghanistan. 
Table 2. Importance delay of causes reported by parties

\begin{tabular}{|c|c|c|c|}
\hline No & Client & Contractor & Consultant \\
\hline 1 & Security & Security & Security \\
\hline 2 & $\begin{array}{l}\text { Poor qualification of the } \\
\text { contractor's technical staff }\end{array}$ & $\begin{array}{l}\text { Delay in progress } \\
\text { payments by owner }\end{array}$ & $\begin{array}{l}\text { Poor qualification of the } \\
\text { contractor's technical staff }\end{array}$ \\
\hline 3 & $\begin{array}{l}\text { Difficulties in financing } \\
\text { project by contractor }\end{array}$ & Corruption & $\begin{array}{l}\text { Type of project bidding } \\
\text { and award (negotiation, } \\
\text { lowest price and etc.) }\end{array}$ \\
\hline 4 & Unqualified workforce & $\begin{array}{l}\text { Suspension of work by } \\
\text { owner }\end{array}$ & $\begin{array}{l}\text { Poor site management and } \\
\text { supervision by contractor }\end{array}$ \\
\hline 5 & $\begin{array}{l}\text { Poor communication and } \\
\text { coordination by contractor } \\
\text { with other parties }\end{array}$ & $\begin{array}{l}\text { Inadequate design-team } \\
\text { experience }\end{array}$ & Corruption \\
\hline 6 & $\begin{array}{l}\text { Insufficient data collection } \\
\text { and survey before design }\end{array}$ & $\begin{array}{l}\text { Late in revising and } \\
\text { approving } \\
\text { documents by owner }\end{array}$ & $\begin{array}{l}\text { Ineffective planning and } \\
\text { scheduling of project by } \\
\text { contractor }\end{array}$ \\
\hline 7 & Corruption & $\begin{array}{l}\text { Change orders by owner } \\
\text { during construction }\end{array}$ & $\begin{array}{l}\text { Frequent change of sub- } \\
\text { contractors because of } \\
\text { their inefficient work }\end{array}$ \\
\hline 8 & $\begin{array}{l}\text { Ineffective planning and } \\
\text { scheduling of project by } \\
\text { contractor }\end{array}$ & $\begin{array}{l}\text { Bureaucracy in } \\
\text { Government agencies }\end{array}$ & $\begin{array}{l}\text { Bureaucracy in } \\
\text { Government agencies }\end{array}$ \\
\hline 9 & $\begin{array}{l}\text { Frequent change of sub- } \\
\text { contractors because of their } \\
\text { inefficient work }\end{array}$ & $\begin{array}{l}\text { Mistakes } \\
\text { discrepancies in design } \\
\text { documents }\end{array}$ & $\begin{array}{l}\text { Difficulties in financing } \\
\text { project by contractor }\end{array}$ \\
\hline 10 & $\begin{array}{l}\text { Poor site management and } \\
\text { supervision by contractor }\end{array}$ & $\begin{array}{l}\text { Delays in producing } \\
\text { design documents }\end{array}$ & $\begin{array}{l}\text { Delay in progress } \\
\text { payments by owner }\end{array}$ \\
\hline
\end{tabular}

Table 3. Significant causes of delay

\begin{tabular}{|l|c|c|c|c|c|c|c|c|}
\hline \multirow{2}{*}{ Cause of delay } & \multicolumn{2}{|c|}{ Client } & \multicolumn{2}{c|}{ Contractor } & \multicolumn{2}{c|}{ Consultant } & \multicolumn{2}{c|}{ Overall } \\
\cline { 2 - 10 } & Index & Rank & Index & Rank & Index & Rank & Index & Rank \\
\hline Security & 0.886 & 1 & 0.933 & 1 & 0.920 & 1 & 0.913 & 1 \\
\hline Corruption & 0.827 & 7 & 0.825 & 3 & 0.838 & 5 & 0.830 & 2 \\
\hline $\begin{array}{l}\text { Poor qualification of the } \\
\text { contractor's technical staff }\end{array}$ & 0.857 & 2 & 0.688 & 17 & 0.850 & 2 & 0.798 & 3 \\
\hline $\begin{array}{l}\text { Delay in progress } \\
\text { payments by owner }\end{array}$ & 0.732 & 21 & 0.844 & 2 & 0.726 & 10 & 0.767 & 4 \\
\hline $\begin{array}{l}\text { Poor site management and } \\
\text { supervision by contractor }\end{array}$ & 0.772 & 10 & 0.688 & 22 & 0.839 & 4 & 0.766 & 5 \\
\hline $\begin{array}{l}\text { Ineffective planning and } \\
\text { scheduling of project by } \\
\text { contractor }\end{array}$ & 0.800 & 8 & 0.643 & 32 & 0.837 & 6 & 0.760 & 6 \\
\hline
\end{tabular}




\begin{tabular}{|l|c|c|c|c|c|c|c|c|}
\hline $\begin{array}{l}\text { Type of project bidding } \\
\text { and award (negotiation, } \\
\text { lowest price and etc.) }\end{array}$ & 0.745 & 16 & 0.689 & 21 & 0.840 & 3 & 0.758 & 7 \\
\hline $\begin{array}{l}\text { Difficulties in financing } \\
\text { project by contractor }\end{array}$ & 0.833 & 3 & 0.662 & 43 & 0.760 & 9 & 0.752 & 8 \\
\hline $\begin{array}{l}\text { Poor communication and } \\
\text { coordination by contractor } \\
\text { with other parties }\end{array}$ & 0.83 & 5 & 0.689 & 16 & 0.725 & 11 & 0.748 & 9 \\
\hline $\begin{array}{l}\text { Frequent change of sub- } \\
\text { contractors because of } \\
\text { their inefficient work }\end{array}$ & 0.791 & 9 & 0.623 & 45 & 0.800 & 7 & 0.738 & 10 \\
\hline
\end{tabular}

\subsection{Ranking of Sources (Groups) of Delays}

The causes are categorized into nine groups. Rankin of these groups associated with degree of severity by clients, contractors and consultants are shown in Table 4 - 7. Tables 4 - 6 present that, both client and consultant specified 'contractor', and 'materials' causes as sources of delay. However, Contractor indicated that 'designer' and 'client' mostly contribute to construction delays. The combined results shown in Table 7 presents that delay in construction projects is mostly originated by the 'contractor', followed by 'designer' and 'materials', while 'project related cause' is less important.

\subsection{Importance Rank Correlation}

The Spearman's rank correlation coefficient is applied to measure the degree of agreement or disagreement associated with the importance ranking of each two stakeholders for a single factor of delay, while ignoring the ranking of the third party. The results present that the highest degree of agreement is between clients and contractors which is $60.5 \%$. The lowest degree of agreement is between contractors and consultants which is 54\%. The relative agreement between each two parties is shown in Table 8 .

Table 4. Ranking of Sources (Groups) of Delays by client

\begin{tabular}{|l|c|c|}
\hline \multirow{2}{*}{ Sources (Groups) of delay by 'Client' } & \multicolumn{2}{|c|}{ Degree of Severity } \\
\cline { 2 - 3 } & Index & Rank \\
\hline Contractor-related factors & 0.732 & 1 \\
\hline Designer-related factors & 0.696 & 2 \\
\hline Materials-related factors & 0.668 & 3 \\
\hline Labor-related factors & 0.651 & 4 \\
\hline Consultant-related factors & 0.644 & 5 \\
\hline Equipment-related factors & 0.64 & 6 \\
\hline Client-related factors & 0.631 & 7 \\
\hline External factors & 0.606 & 8 \\
\hline Project-related factors & 0.605 & 9 \\
\hline
\end{tabular}


Table 5. Ranking of Sources (Groups) of Delays by contractor

\begin{tabular}{|l|c|c|}
\hline \multirow{2}{*}{ Sources (Groups) of delay by 'Contractor' } & \multicolumn{2}{|c|}{ Degree of Severity } \\
\cline { 2 - 3 } & Index & Rank \\
\hline Designer-related factors & 0.684 & 1 \\
\hline Client-related factors & 0.665 & 2 \\
\hline Contractor-related factors & 0.635 & 3 \\
\hline Materials-related factors & 0.632 & 4 \\
\hline Consultant-related factors & 0.631 & 5 \\
\hline Equipment-related factors & 0.617 & 6 \\
\hline External factors & 0.598 & 7 \\
\hline Labor-related factors & 0.565 & 8 \\
\hline Project-related factors & 0.563 & 9 \\
\hline
\end{tabular}

Table 6. Ranking of Sources (Groups) of Delays by consultant

\begin{tabular}{|l|c|c|}
\hline \multirow{2}{*}{ Sources (Groups) of delay by 'Consultant' } & \multicolumn{2}{|c|}{ Degree of Severity } \\
\cline { 2 - 3 } & Index & Rank \\
\hline Contractor-related factors & 0.714 & 1 \\
\hline Materials-related factors & 0.639 & 2 \\
\hline Client-related factors & 0.637 & 3 \\
\hline External factors & 0.630 & 4 \\
\hline Consultant-related factors & 0.613 & 5 \\
\hline Labor-related factors & 0.606 & 6 \\
\hline Equipment-related factors & 0.600 & 7 \\
\hline Designer-related factors & 0.599 & 8 \\
\hline Project-related factors & 0.597 & 9 \\
\hline
\end{tabular}

Table 7. Ranking of Sources (Groups) of Delays combined results

\begin{tabular}{|l|c|c|}
\hline \multirow{2}{*}{ Sources (Groups) of delay 'Combined results' } & \multicolumn{2}{|c|}{ Degree of Severity } \\
\cline { 2 - 3 } & Index & Rank \\
\hline Contractor-related factors & 0.71 & 1 \\
\hline Designer-related factors & 0.667 & 2 \\
\hline Materials-related factors & 0.647 & 3 \\
\hline Labor-related factors & 0.638 & 4 \\
\hline Consultant-related factors & 0.629 & 5 \\
\hline Equipment-related factors & 0.621 & 6 \\
\hline Client-related factors & 0.61 & 7 \\
\hline External factors & 0.59 & 8 \\
\hline Project-related factors & 0.588 & 9 \\
\hline
\end{tabular}


Table 8. Importance Rank Correlation

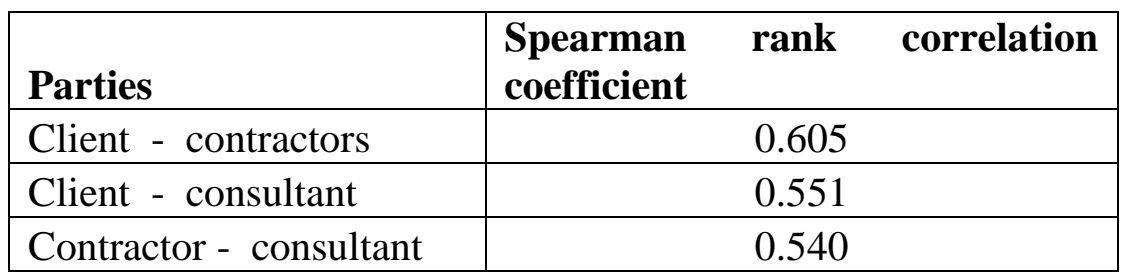

\section{Summary and Conclusion}

Construction delay in Afghanistan is explained through literature review and field survey. Through in-depth literature review 83 causes of delay were identified, the factors combined into nine groups. Three major stakeholders, including 20 client, 25 contractors and 15 consultants responded the questionnaire forms. The respondents reported that contract with less than 12 months highly contributes to delays. The most common time spent for the most delayed projects in Afghanistan is between 1 to 6 months.

The importance index was used to rank the effect of each cause of delay. It was found that only two causes of delay are common between all parties, which are 'security' and 'corruption'. Clients like consultants agreed that ineffective planning and scheduling of project by contractor, poor qualification of the contractor's technical staff and difficulties in financing project by contractor are the most sever causes of delay by the contractors. Whereas, the contractor reported that delay in progress payment by the client is one of the significant causes of delay.

Contractor indicates that designer and client are the significant source of delays, while both client and consultant specified 'contractor', and 'materials' causes as sources of delay. The combined result of group causes shown that mostly the delay is caused by the 'contractor', followed by 'designer' and 'materials', while 'project related cause' is less important. The value of Spearman's rank presents that the highest degree of agreement is between clients and contractors which is $60.5 \%$. The lowest degree of agreement is between contractors and consultants which is $54 \%$.

The importance index was used to rank the significant causes of delay, and it was found that top 10 major causes of construction delays in Afghanistan are security and corruption followed by poor qualification of the contractor's technical staff, poor site management and supervision by contractor, ineffective planning and scheduling of project by contractor, and difficulties in financing project by contractor. Delay in progress payments by owner and type of project bidding and award (negotiation, lowest price) are another critical factors which contribute to construction delays.

\section{Recommendations}

\subsection{General Recommendations}

The following points can be recommended in order to reduce the impact of delays in construction projects in Afghanistan:

1. Security issues have prevented some projects from being completed on schedule. Poor security is the most difficult challenges that stakeholders face in implementing 
construction projects. The security concerns in some parts particularity in south and south east of Afghanistan has delayed projects and increased costs. Therefore, more attention is required to be considered in maintaining security situations to provide opportunities for contractors to complete the projects on timely manner.

2. Corruption constitutes a serious threat to Afghanistan Construction Industry improvement as it has significant effects on construction delays. There is an urgent need for developing a legal framework for fighting corruption, whereas the current framework has been outdated and unclear.

3. Another critical factor is 'poor site management and supervision by contractor'. There is a need for contractor in improving abilities of managers, engineers which is a vast demand in successful completion of projects. Thus, the contractors have to adapt some essential innovative management techniques, including organizing and controlling, and team building and value engineering that may be more efficient and effective. Having applied these techniques, it would guarantee to reduce the risk of such critical factors.

4. Ineffective planning and scheduling has also a major impact on construction delays. Effective planning and programming of a project is a must to secure early completion of the project. The planning process should be developed from start of the project until completion of a project. The planning stages should be devised very carefully, starting from strategic, tactical and operational planning.

5. Another problem in contributing delays in Afghanistan is difficulties in financing project by contractor. A serious attention must be paid in project feasibility. A vivid mechanism for selecting the contractors who are financially capable to run the projects without incurring delays is a must.

6. Delay in progress payment by client is a critical cause of delays, and as a result many projects are behind schedule in Afghanistan. There is a serious need for the clients to devise an explicit mechanism to speed up the payment process. The qualified consultants and quantity surveyors, who are often responsible for issuing the calculating and payment certificates, should be employed to ease the process. On the other hand, Bureaucracy in government agencies also suspends the payment progress. Therefore, it is advised that the government should find a way how to narrow down the process.

\subsection{Recommendation for Parties}

To minimize and control delays in construction projects, the following issues can be recommended by all parties:

\subsubsection{Client}

The clients should pay special attention to the following factors:

- Pay progress payment to the contractors on time as it weakens the contractors ability to finance the work

- Minimize changes in order during construction so as to avoid delays

- Speed up reviewing and approving of design documents

\subsubsection{Contractor}

The contractors should give more attention to the following factors:

- Improve the knowledge and skills of technical staff

- Manage the financial resources and plan cash flow by utilizing progress payment 
- Planning and scheduling the works from start of project and during the work to match with the resources and time to develop the work to avoid delays

- Improve site management and supervision to achieve completion of work within specified time

\subsubsection{Consultant}

Consultants should focus on the following points:

- Avoid delays in reviewing and approving design documents

- Build up the knowledge and skills of technical staff

- Improve coordination between parties

\subsection{Recommendations for future studies}

More research on construction delays should be done in order to develop guidelines, or methods of minimizing the effects of construction delays in Afghanistan. Furthermore, similar research should be performed in various provinces or cities of Afghanistan. In order to providing more reliable data it is required to carry out studies for each specific type of construction projects, including highways, dam construction projects, utilities and etc. Surely, detailed surveys required to be performed to find out the effect of financing and cash flow problems on delays in construction projects.

\section{References}

Al Khalil, M. and Ghaflu, M.A. (1999) Delay in public utility projects in Saudi Arabia. International Journal of Project Management, 17(2), 101-106.

Al-Momani, A.H. (2000) Construction delays: a quantitative analysis. International Journal of Project Management, 18(1), 5-9.

Assaf, S.A., Al-Khalil, M. and Al-Hazmi, M. (1995). Causes of Delay in Large Building Construction Projects. Journal of Project Management in Engineering ASCE, 2; 45-50.

Assaf, S.A. and Al Hejji, S. (2006) Causes of delay in large construction projects. International Journal of Project Management, 24, 349-357.

Chan, D.W.M. and Kumaraswamy, M.M. (1997) An evaluation of construction time performance in the building industry. Journal of Building and Environment, 31(6), 569-578.

Kaming, P.F., Olomolaiye, P.O., Holt, G.D., and Harris, F.C. (1997) Factors influencing construction time and cost overruns on highrise projects in Indonesia. Journal of Construction Management and Economics, 15(1), 83-94.

Koushki, P.A., Al-Rashid, K., and Kartam, N. (2005) Delays and cost increases in the construction of private residential projects in Kuwait. Construction Management and Economics, 23(3), 285-294.

Long, L.H., Lee, Y.D. and Lee, J. Y. (2008) Delay and Cost Overruns in Vietnam Large Construction Projects:A Comparison with Other Selected Countries. Journal of Civil Engineering, 12(6), 367-377.

Mezher, T.M. and Tawil, W. (1998) Causes of delays in the construction industry in Lebanon. Engineering, Construction and Architectural Management 5(3), 252-260.

Trauner, J.T., Manginelli, W.A., Lowe, J.S., Nagata, M.F. and Furniss, B.J. (2009) Construction Delays: understanding them clearly and Delay Analysis in Construction Analyzing them correctly. London: Elsevier Inc. 